\title{
Convalescent plasma, political narrative, and public health ethics in the Covid-19 pandemic
}

\author{
SIMRAN AGRAWAL, ANUP AGARWAL, YOGESH JAIN
}

\begin{abstract}
Convalescent plasma therapy emerged as an early experimental therapy for the treatment of Covid-19. However, despite limited data regarding its safety and efficacy, the therapy was extensively publicised by multiple politicians as a cure. We analyse the impact of this political narrative around medical therapeutics on the pandemic using the coherentist model of public health ethics. The clinical benefits of the therapy are evaluated in terms of reduction in mortality and disease progression as compared to the potential transfusionrelated adverse events. Political advocacy of therapeutics might hamper the autonomy and decision-making of individuals and institutions. Marketing and monetisation of convalescent plasma might cause inequitable distribution and unregulated use. It also creates an economic burden on the government and healthcare which should be justified by the additional cost/ effectiveness ratio of the therapy. This article exemplifies the inadvertent effects and ethical challenges following political narratives about medical therapeutics and the importance of involving ethics in designing policies concerning public healthcare.
\end{abstract}

Keywords: Covid-19, convalescent plasma therapy, political narrative in covid-19, politicisation of medicine, public health ethics

Authors: Simran Agrawal (agrawalsimran2803@gmail.com), Medical Student, Topiwala National Medical College and BYL Nair Charitable Hospital, Mumbai, Maharashtra, INDIA; Anup Agarwal (mailanupagarwal@gmail.com) Public Health Practitioner, People's Association for Equity and Health, Ambikapur, Surguja, Chhattisgarh, INDIA; Yogesh Jain (corresponding author yogeshjain.chhattisgarh@gmail.com) Public Health Practitioner, People's Association for Equity and Health, Ambikapur, Surguja, Chhattisgarh, INDIA.

To cite: Agrawal S, Agarwal A, Jain Y. Convalescent plasma, political narrative, and public health ethics in the Covid-19 pandemic. Indian J Med Ethics. 2021 Jul-Sep; 6(3) NS: 226-228. DOI:10.20529/IJME.2021.029

Published online on April 24, 2021.

Manuscript Editor:Vijayaprasad Gopichandran

(c) Indian Journal of Medical Ethics 2021
On the evening of May 15, 2020, I (SA) enrolled the first two patients, GJ and PR, at our institution in the PLACID trial, a randomised controlled trial on the efficacy of convalescent plasma (CP) in Covid-19 (1). They were randomised into the treatment arm (standard Covid-19 care + Convalescent plasma therapy) and the control arm (Standard Covid-19 care only), respectively.

At $1 \mathrm{am}$, in a ward full of patients fighting for each breath and the monitors creating a cacophony, I put my hopes in the bag of CP to fight the deadly virus. While GJ's condition did not improve, to our surprise PR who had not received the new treatment, recovered. We subsequently enrolled 27 patients at our institution, 14 of whom received the plasma. However, there was no obvious evidence to suggest that the therapy had in any way improved the clinical outcome. Moreover, on completion of the enrollment of 464 patients across the 39 trial sites, there was no benefit of $\mathrm{CP}$ in the reduction of mortality or disease progression from moderate to severe disease.

While the trial was still in its early phase in May, helping us convert clinical equipoise into tangible data, a narrative rooted in populism and appeasement was being propagated by politicians in the popular media, based on anecdotal evidence about the ability of CP to fight Covid-19 (2). Such publicising of medical therapeutics by political leaders may allow for early authorisation and expeditious provision of life-saving drugs, but can also result in a dilemma for health professionals that needs to be analysed through the lens of public health ethics.

We look to the coherentist model of public health ethics to analyse this ethical dilemma (3). It describes a methodological approach to the ethical practice of public health and provides five normative criteria which are: expected benefit; expected harm; impact on public autonomy; impact on equity; and expected efficiency. We have added the impact on informed consent along with autonomy, in relevance to the CP therapy.

\section{Expected benefit of convalescent plasma}

The benefit of $\mathrm{CP}$ can be measured in terms of reduced mortality, prevention of disease progression, negative conversion to SARS-CoV-2 viral RNA, decreased duration of 
hospital stay, and symptomatic relief. A randomised clinical trial with 103 patients conducted in China presented an increased negative conversion rate of the Covid-19 RT-PCR but there was no mortality benefit with $C P(4)$. Similar results were reported by the PLACID trial in terms of mortality and negative viral RNA conversion. In early January, 2021, the New England Journal of Medicine (NEJM) published a study favouring the use of high titre $C P$ in the early course of Covid-19 (5). While this advancement provides further insight into the role of $C P$, there was no significant evidence to support its use in June 2020, when CP found its way into the clinical management protocol of Covid-19.

\section{Potential harm of convalescent plasma}

Although it was historically considered a safe modality, CP transfusion can cause adverse events ranging from a mild rash to life-threatening lung injuries like Transfusion Related Acute Lung Injury (TRALI) and Transfusion Associated Circulatory Overload (TACO) (6). Covid-19 causes various pulmonary pathologies including thrombosis, embolism, and pneumonia. This pulmonary thrombosis may be worsened by the pro-thrombotic effects of plasma. Moreover, it is difficult to distinguish TRALI and TACO from the worsening pulmonary pathology due to Covid-19 and may lead to under-reporting of adverse events associated with CP (7).

The political statements on medical therapeutics and subsequent emergency authorisations are probably the results of a compelling "need to act" in a public health emergency (8). Nonetheless, they may impede the larger interests of public health by compromising the ability to recruit participants in clinical trials essential to determine the safety and efficacy of the therapy (9). While screening patients for the PLACID trial, we observed that patients would routinely opt for the off-label plasma therapy but were reluctant to consent to enrolment in the clinical trial as they feared they may not get the desired treatment.

\section{Impact on informed consent and autonomy}

The information shared by various leaders on news and social media, highlighting only the expected advantages of $\mathrm{CP}$ may cause a positive bias in the minds of the population, obstructing their ability to make a well-informed, voluntary decision (10).

While the effect on individual patients is obvious, a more insidious effect is seen on the policymakers. CP made its way into the clinical management protocol of Covid-19 issued by the Ministry of Health, Government of India, as early as midJune 2020 (11) and was authorised for emergency use by the US-FDA in August 2020 (12). Furthermore, the advisory remained unaltered even after two months of publication of trial data (1). While the Indian Council of Medical Research had put out a revised advisory, that is unlikely to check the unscrupulous use of CP (13).

\section{Marketing and monetisation: disparity in accessibility and equity}

The financial burden of CP therapy should be considered for ensuring equity in distribution. There was a sudden upsurge in the demand for CP due to the hype. This facilitated a flourishing black market for the sale of CP in India. Stories of patient families spending exorbitant amounts to buy CP from potential donors were reported (14). Despite the laws against monetary compensation for blood and blood products, there were reports of compensation for plasma donation from both the private and public sectors in India (15).

\section{Cost-effectiveness analysis}

In a resource-limited setting, it is imperative to allocate funds after analysing the effectiveness of the modality in comparison to other preventive and curative interventions. The process of plasma collection using apheresis, antibody testing, storage, and transfusion of CP is time-consuming, expensive, and requires a special setting and machinery (16). The pandemic has created a heavy burden on the healthcare system in the form of a shortage of hospital beds, human resources, and healthcare facilities for patients with and without Covid-19. There is an increased demand for the essential protective equipment for healthcare workers, sanitation, and infection control amenities along with the other overheads of the pandemic. Thus, it is crucial to use resources and services cautiously in a well-planned manner $(17,18)$.

Marckmann et al (3) describe the conditions for fair decisionmaking in public health. This includes transparency, consistency, justification, participation, managing conflict of interest, openness for revision, and regulation. Announcements made during election campaigns, political speeches may not be conducive to a fair decision-making process as outlined above and thus overlook public health ethics.

This is just one example of political influence on the use of $\mathrm{CP}$ from India during this pandemic. This is not unique. There have been similar narratives creating public health dilemmas around Hydroxychloroquine and now Covid-19 vaccine (19) not only in India and the USA, but in many other countries.

Political leaders design policies and guide their governance when put into practice. In the setting of a pandemic, these roles demanded that they take the help of experts in health, finance, governance, implementation, and other allied departments. In democracies, they are elected by the people and thus have an additional responsibility to keep the people informed and engage with them for decentralised decision making. We make a case for including principles of public health ethics in their decision making and dialogue with the community.

This also places the onus on our institutions guided by public health professionals, healthcare professionals, 
government officials, and other policymakers to design systems, policies, and protocols rooted in ethics and not in political influence.

\section{Competing interests and funding: None to declare}

\section{References}

1. Agarwal A, Mukherjee A, Kumar G, Chatterjee P, Bhatnagar T, Malhotra P. Convalescent plasma in the management of moderate covid-19 in adults in India: open-label phase II multicentre randomized controlled trial (PLACID Trial). BMJ 2020 Oct 22;371: m3939. Available from: http://www.bmj.com/content/371/ bmj.m3939.abstract

2. PTI. COVID-19: Won't stop clinical trials of plasma therapy as initial results are good, says Arvind Kejriwal. 2020 May 1[cited 2021 Jan 28]. Available from https://economictimes.indiatimes.com/news/ politics-and-nation/covid-19-wont-stop-clinical-trials-of-plasmatherapy-as-initial-results-are-good-says-arvind-kejriwal/articleshow/ $75487345 . \mathrm{cms}$

3. Marckmann G, Schmidt H, Sofaer N, Strech D. Putting public health ethics into practice: A systematic framework. Front Public Heal. 2015 Feb 6;3:1-8. Available from: doi:10.3389/fpubh.2015.00023

4. Li L, Zhang W, Hu Y, Tong X, Zheng S, Yang J, et al. Effect of convalescent plasma therapy on time to clinical improvement in patients with severe and life-threatening COVID-19: A randomized clinical trial. JAMA. 2020 Aug 4[cited 2021 Jan 28]; 324(5):460-70. Available from: https://doi.org/10.1001/jama.2020.10044

5. Libster R, Pérez Marc G, Wappner D, Coviello S, Bianchi A, Braem V, et al.. Early high-titer plasma therapy to prevent severe Covid-19 in older adults. N Engl J Med. 2021 Feb 18; 384(7), 610-18. Doi: https:// doi.org/10.1056/NEJMoa20337

6. Casadevall A, Pirofski LA. The convalescent sera option for containing COVID-19. J Clin Invest. 2020 Apr 1;130(4):1545-8.

7. Pathak EB. (2020). Convalescent plasma is ineffective for covid-19. BMJ. 2020 Oct 22; 371: m4072. https://doi.org/10.1136/bmj.m4072

8. Angus DC. Optimizing the trade-off between learning and doing in a pandemic. JAMA. 2020 May 19;323(19):1895-6.

9. Thomas K, Weiland N. As Trump praises Plasma to treat Covid-19, researchers struggle to finish critical studies. New York Times. 2020 Aug 4[cited 2021 Jan 28]. Available from: https://www.nytimes.com/
2020/08/04/health/trump-plasma.html?searchResultPosition=3

10. Aquino YSJ, Cabrera N. Hydroxychloroquine and COVID-19: Critiquing the impact of disease public profile on policy and clinical decision-making. J Med Ethics. 2020 Sep; 46(9):574-8.

11. Ministry of Health and Family Welfare, Govt of India. Clinical Management Protocol: COVID-19. New Delhi: MoHFW, Gol; 2020 Jun 13[cited 2021 Jan 28]. Available from https://www.mohfw.gov.in/ pdf/ClinicalManagementProtocolforCOVID19.pdf

12. Brennan Z, Owermohle S. FDA authorizes plasma treatment despite scientists' objections. Politico. 2020 Aug 23[cited 2021 Jan 28]. Available from: https://www.politico.com/news/2020/08/23/ plasma-treatment-coronavirus-fda-trump-400390

13. Indian Council of Medical Research. Evidence Based Advisory to address Inappropriate Use of Convalescent Plasma in COVID-19 Patients. New Delhi: ICMR; 2020 Nov 17[cited 2021 Jan 28]. Available from:https://www.icmr.gov.in/pdf/covid/techdoc/ ICMR ADVISORY Convalescent plasma 17112020 v1.pdf

14. Khan J, Hizbullah M, Jain N, Exclusive: Coronavirus pandemic fuels black-market for the plasma of recovered. India Today, $2020 \mathrm{Ju}$ 22[cited 2021 Jan 28]. Available from https://www.indiatoday.in/ india/story/exclusive-coronavirus-pandemic-fuels-black-market-forplasma-of-recovered-patients-1703332-2020-07-22

15. Agarwal KK. Wooing plasma donors. 2020 Jul 25[cited 2021 Jan 28].; Available from https://www.indialegallive.com/special-story/ wooing-plasma-donors/

16. Epstein J, Smid WM, Wendel S, Somuah D, Burnouf T. Use of COVID19 convalescent plasma in low- and middle-income countries: a call for ethical principles and the assurance of quality and safety. Vox Sang. 2020 Jan; 116(1):13-14. doi: 10.1111/vox.12964. Epub 2020 Jun 24.

17. Gostin LO, Friedman EA, Wetter SA. Responding to Covid-19: How to Navigate a Public Health Emergency Legally and Ethically. Hastings Cent Rep. 2020 Mar 26;50(2):8-12.

18. Emanuel EJ, Persad G, Upshur R, Thome B, Parker M, Glickman A, et al. Fair Allocation of Scarce Medical Resources in the Time of Covid19. N Engl J Med. 2020 Mar 23;382(21):2049-55. Available from: https://doi.org/10.1056/NEJMsb2005114

19. PTI. Coronavirus | All Indians to get free COVID-19 vaccine, says Union Minister. Hindu. 2020 Oct 25[cited 2021 Jan 28]. Available from: https://www.thehindu.com/news/national/coronavirus-allindians-to-get-free-covid-19-vaccine-says-union-minister/ article32940902.ece\# 